\title{
SOME REFLECTIONS ON CONTEMPORARY IRISH POETRY: AN INTERVIEW WITH THEO DORGAN
}

\author{
Pilar Villar Argáiz
}

Conocí a Theo en su visita a Granada en 1998. Aún así, no fue éste su primer viaje a Andalucía. Su fascinación por Lorca había sido ya motivo de numerosas visitas a España. Desde entonces, hemos mantenido una amistad que ha sido altamente enriquecedora y gratificante. Su personalidad arrolladora, su carisma y sus inquietudes literarias motivaron mi primer acercamiento a la poesía irlandesa. Este apartado no es más que un reconocimiento no sólo a su persona sino a su admirable obra poética, reflejo de una Irlanda contemporánea consciente de su historia colectiva de marginación y violencia, pero abierta, tras varias décadas de exilio, al contexto europeo.

Theo Dorgan nació en Cork en 1953. Habiendo completado sus estudios en Inglés y Filosofía en la universidad de Cork, ejerció como tutorando en esta universidad, compaginando dicho trabajo con un puesto oficial en el Triskel Arts Centre en Cork.

En 1989 se trasladó a Dublín, donde reside en la actualidad con Paula Meeham, poetisa de considerable reconocimiento nacional. Durante varios años ha sido director de Poetry Ireland, organización nacional de poesía. Ha dirigido una amplia variedad de programas literarios de radio y televisión, como en la cadena nacional RTÉ. Desde 1982, se le puede escuchar frecuentemente en BBC radio, haciendo entrevistas a escritores en alza del panorama literario irlandés. Entre sus amplias actividades culturales, también destaca su participación como codirector del festival de cine de Cork.

Sus volúmenes de poesía incluyen Slow Air (1975), The Ordinary House of Love (1991), A Mozcow Quartet (1992), Rosa Mundi (1995) y Sappho's Daughter (1998). También ha publicado una selección de su obra al italiano, La Case ai Margini del Mundo (1999), y una traducción al español de Sappho’s Daughter (Madrid, Ediciones Hiperión, 2001). A su vez, ha ejercido como editor de The Great Book of Ireland (junto con Gene Lambert, 1991), Revising the Rising (con Máirín Ní Dhomnnachadha, 1991), Irish Poetry since Kavanagh (1995), y Watching the River Flow (junto con Noel Duffy, 1999). Entre sus premios destaca el Listowel Prize for Poetry, en 1992.

\footnotetext{
* Becaria Predoctoral MECD, Departamento de Filologías Inglesa y Alemana, Universidad de Granada; $\bowtie$ pvillar@ugr.es.
} 
I met Theo in his last visit to Granada in 1998. It wasn't, nevertheless, his only trip to Andalucía. His fascination for Lorca had prompted numerous journeys to the South of Spain. Since then, we have maintained a friendship which has been highly sustaining and gratifying for me. His overwhelming personality and overpowering charisma, as well as his literary interests, forged my initial relationship with Irish poetry. This brief section is not only a recognition for his many personal attributes, but also for his admirable poetic work, a reflection of a contemporary Ireland which is aware of its collective history of violence and displacement, but opened, after decades of seclusion, to the European context.

Theo Dorgan was born in Cork in 1953. Having completed a BA in English and Philosophy and a MA in English at University College Cork, Dorgan lectured in that University, while simultaneously working as Literature Officer with Triskel Arts Centre in Cork. In 1989, he moved to Dublin, where he now lives with the well-known Irish woman poet Paula Meehan. He has been Director of Poetry Ireland, the national poetry organisation, and has presented a wide variety of radio and television literary programmes over the years, as in the national channel RTE. As a broadcaster since 1982 he is also frequently heard on BBC radio. Among his various cultural activities, it should be highlighted his participation as co-director of the film festival in Cork.

His volumes of poetry include Slow Air (1975), A Moscow Quartet, The Ordinary House Of Love (1991), Rosa Mundi (1995), and the long poem, Sappho's Daughter (1998, Wave-Train Press), which has been translated into Spanish, La Hija de Safo (Madrid, Ediciones Hiperón, 2001). A selection of his poetry has been translated into Italian, $\mathrm{La}$ Case ai Margini del Mundo (1999). Apart from writing, Dorgan has also worked as editor of a collection of essays, Irish Poetry After Kavanagh (1995), and coeditor of the Great Book Of Ireland (together with Gene Lambert, 1991), Revising the Rising (with Máirín Ní Dhomnnachadha 1991), and Watching the River Flow (with Noel Duffy, 1999). He has received many honors and awards, among them the Listowel Prize for Poetry, in 1992.

\section{January 2003, Dublin}

PILAR VILLAR: It is amazing how Ireland, such a small country (barely 84,000 square kilometres) can generate such a rich literature, capable of modifying the world's literature. Which do you think are the reasons for this?

Theo Dorgan: Nobody knows the real answer to this, and contemporary Irish writers are for the most part convinced that our influence on world writing has been somewhat exaggerated. That said, I am sure that our experience of being colonised by English is a major part of the explanation. You have a situation where an existing written and oral culture in Gaelic is suddenly overlaid with a powerful language of war, commerce, politics and trade - a language whose operational domain is vastly wider than the native domain, and a language, moreover, which has gone on to become a world language of sorts. English only became a parallel vernacular in Ireland at the beginning of the $19^{\text {th }}$ century, a time when America was taking off as the cradle of the modern, an America into which millions of the Irish poor were being decanted with already one priceless advantage, a grasp of the 
language. Think, by contrast, of the disadvantages experienced by Sicilians, Galicians, Jews from Eastern Europe. This established in Irish literature a kind of premature vantage point from which an Irish writer, coming out of what was still a mediaeval political culture, a subaltern culture, could nevertheless access an audience of considerable sophistication in both the United Kingdom and the emerging America. The next consideration has to be the fluidity of perspective and language which also flows from our colonised status: we had still the Irish language, a kind of permanent reservoir of subversive possibility in itself and in the way in which its syntax inflected and shaped a peculiarly Irish voice inside the confines of standard English. As well as this, we have to consider the development of Hiberno-English, a distinctively Irish resource of phrase, vocabulary and usage.

Cumulatively, by the beginning of the $20^{\text {th }}$ century Irish writers had come to a sophisticated grasp of the language but stood at a defined slant to its metropolitan refinement. (You can see something like the same process at work in the English of St. Lucia, used to powerful effect by Derek Walcott).

The net effect is that the English we speak in Ireland has a suppleness and an inbuilt principle of scepticism that makes it natural for an Irish writer to speak and write in a voice, like that of her or his primary audience, which is in effect a reconquering of the conqueror.

A colonised people revenges itself on the conqueror at an unconscious level by imaginatively appropriating the conqueror's language and making better use of it. I do not underestimate this drive.

Heidegger says that every language is a map of the world: we write ourselves into the map of the world in an English language that is not the English of the English — and so we transcend, in some sense, that linguistic barrier, we make ourselves free in the world as ghost neighbours of the world's other languages, and as near-neighbours in the prelinguistic or non-linguistic imagination. (Now there's a sentence that will get me into trouble).

But, doesn't something similar happen with the Spanish of, say, Neruda or Marquez?

If this small country has what sometimes seems, to others, a disproportionate presence in world literature, it is probably because we are a small and tenacious virus inside the host-body of the wider English language.

But, we don't think of such things when we write...

Pv: Your public projection within the Irish literary arena started, as far as I am concerned, in 1975, with the publication of your volume of poetry Slow Air. How was your first attempt within the poetic panorama of Ireland? Encouraging or disappointing?

TD: In 1975, when still a student, I published a small pamphlet of poems, very bad poems. I never thought, when I was a child, that I would write poems: I thought I would be a novelist. I think the best and most accurate thing to say is, poetry found me, and it won't go away. As soon as I began to write poems, thought I knew they were bad poems, I knew I was stuck with this as a puzzle for the rest of my life. I had only a passing interest in the idea of a literary career, and I soon realise that one has a life in poetry, not a career. When I met Robert Graves, and began to read him with great seriousness, I found a kindred spirit: 
like Graves, I believe that a life in poetry is a life of service to poetry. I have the normal bouts of rage at stupid or uncomprehending reviews, but they pass more quickly now. There is a real sense in which I am becoming year by year more indifferent to the literary life: all I really care about is writing the next poem, - and the poems must find their own way in the world. I never think of a poem as 'mine', though I am sometimes pleased and moved when a stranger writes to say a poem has meant something in their life.

$\mathrm{Pv}$ : In 1989 you moved from Cork to Dublin. How would you qualify the literary atmosphere of then, as compared to the present? How do you find, at the moment, the poetic panorama in contemporary Ireland?

TD: When I came to Dublin in 1989 there was an older generation of writers who sustained the illusion of Dublin Literary Life, in capital letters. I knew this was nonsense, and it becomes more nonsensical with every year that passes. It is no longer necessary for writers to huddle defensively around a dying fire, whining about neglect. The State supports its writers, up to a point, censorship is emphatically a thing of the past and most contemporary Irish writers would say they have access to an audience, here and abroad. Perhaps the most important developments on the last 15 years are so have been the emergence of woman writers on a far bigger scale than in the past, to the profound enrichment of our literature and of our culture in general, and the thoroughgoing internationalisation of our literature in both languages. If I telephone a colleague now and find she's not at home, she's as likely to be in Tokyo as in Tipperary. To stick with poetry, there are maybe 250 Irish poets with books in print at present, and you are as likely to find Kerouac, Lorca or Akhmatova as an influence in a collection — a spiritual comrade as it were- as you are to find Yeats, Kavanagh or Ó Bruadair.

$\mathrm{Pv}$ : Your upbringing and childhood in Cork is reflected in your poetry. You frequently refer to Blackpool, a neighbourhood that, until very recently, could be classified as the typical "Irish neighbourhood", inhabited by natives who were excluded from the city. To what extent does your place of birth shape your poetry?

TD: Cork is a secessionary city, a place with a distinctive dialect of its own inside the larger sphere of Hiberno-English. It is a port city, with extensive historical trading links throughout the world - with Spain and France, with the USA, Latin America, Australia and Africa. As the biggest city in Ireland after Dublin, which housed the colonial power apparatus for centuries, it is also the biggest city in Ireland with an independent sense of itself as Irish. It is, to speak figuratively, a Mediterranean city where Dublin is a Nordic city. It was also, for the period of my childhood, a city the size of Athens in the time of Pericles. From the $15^{\text {th }}$ through the $17^{\text {th }}$ centuries, the walled city at its heart, where the colonists lived, was a small enclave surrounded by a large population with links to small industry such as brewing, distilling, hide tanning and so on, trades and links which essentially knitted the city into its agricultural hinterland. Blackpool, where I grew up, has a strong and long-tailed sense of its own history, a lively and cultured proletariat famous 
for its devotion to sport and opera, a large stock of the older buildings in the city and a sceptical attitude to the bourgeoisie, native and foreign. The people of Blackpool also have a love of reading and travel. My grandfather, for instance, was born at sea, off Cape Horn, my father had booked a ticket to Australia when he met my mother (he cancelled the ticket), I myself saw New York, York and London before I ever saw Dublin.

Yes, I think you could say that my place of birth shaped my poems, in that it shaped my stance towards the world, taught me from an early age that the world is glorious, tragic, colourful and to be doubted.

Pv: Some of your poems deal with the issue of Ireland politics. This is the case of "Kilmainham, Easter" or "Nocturne for Blackpool". Do you consider yourself an Irish poet/writer? That is, to what extent your Irish roots, your Irish nationality shape and determine your poetry? Do you think that reading your poetry requires an understanding of the history of Ireland and its relationship with England?

TD: In the sense I allude to above, I am Irish in that a man from Cork is Irish. I have the option of living anywhere in the world, I have an elective affinity with, to take some concrete examples, Greece, Spain, France and Russia, all places where I feel at home. I acknowledge that Ireland shaped me, that the concretisation of, say, my passion for justice finds its most appropriate outlet in my passion for social and political justice in Ireland. Most of my friends are Irish, though certainly not all, I am most at home in the interstitial nuances of Irish life, though I am comfortable elsewhere.

I am sometimes moved to write a poem about Ireland, more exactly perhaps about events in Ireland, or at least a poem incorporating or dealing directly or obliquely with such events. All this is as natural as breathing. I do not take 'Ireland' or 'Irishness' as a subject matter, I am almost completely indifferent to 'The English Question', there are very few English or Welsh poets who interest me, though there are poets in Scotland whom I admire, Douglas Dunn and Kathleen Jamie come to mind.

\section{Pv: So, how do you view "Irishness", Irish identity?}

TD: How do I view "Irishness"? With considerable scepticism. We have short lives, we are born into a particular place, a particular people, and hence into a particular history and culture. This natal provision shapes our worldview, but a poet cannot, I think, permit this become a constraint. Irishness is important to me only in that it is a resource, a reflex of urgency in speech. I am profoundly aware of the land, the sea, the people, this history, these languages I have inherited. I feel a sense of duty to leave all these things unsullied by my temporary presence, a modest ambition to enrich in some small degree all these inheritances. But I do not consider myself bound to or by these accidents. There are those who trade on "Irishness", I pity them; there are those, like Beckett, who are Irish to the core, but not at home here. Those I understand, and at the same time I understand and admire the traditional singer who finds in her local parish "world enough and time". 
PV: To what extent has the problem of Northern Ireland affected contemporary poets in Ireland, in particular, your poetry?

TD: Events in Northern Ireland over the past 30 years have greatly affected the poetry coming out of that part of the island, especially in terms of how pets from the North have been beneficiaries and victims of a certain prurient media interest: I have the sense that it has been a liberation into a greater amplitude of audience, and a prison, insofar as the poets have been under pressure to function as tribal voices. The best of them are the better for having had to resist and subvert such pressures, I suppose, but I have a profound distrust of the process by which such poetry as has been written is co-opted to meliorist political agendas. In the current climate, as we try to articulate a post Peace Process vision of a shared island, the essentially private visions of poets are sometimes bent and suborned to suit the agendas of people who are indifferent to poetry as such.

The war in the North doesn't feature much in the preoccupations of southern poets. Our little Republic has had to dismantle its nativist first identity, and we have had to painfully create a new, more complex sense of ourselves in response to concrete manifestations of destructive atavisms, and such a process of renewal has found voice in the extraordinary multi-valence of contemporary poetry from Ireland. We have survived, I think, by relocating ourselves in a wider world, a wider sense of ourselves.

I think if there has been a negative effect, it has been that in this wider world there is a kind of cartoon version of Ireland, and hence a simplistic sense of expectation, as if an Irish poet is required to write about and only about Ireland. If I might give a personal example, it seems perfectly natural to Cork people that in Sappho's Daughter I should have written a hymn to the Mediterranean: to Northerners, and to many people in Ireland, this is inexplicable, in England or in the USA it would be incomprehensible — they would want to know "but why aren't you writing about Ireland?".

Pv: In poems like "Statement of the Political Exiles", you deal with the experience of exile as a painful but enabling experience. What is exile in literature / politics / culture? Do you think the Irish poet, or any writer in general, has to be exiled in order to achieve artistic mastery? Why?

TD: We are born into exile on this earth, we go into exile when we die.

Pv: Have you ever felt exiled in your own country, because of political, social or cultural reasons?

TD: I have always been a political, social and cultural inner emigré.

$\mathrm{Pv}$ : At times, you approach issues of contemporary relevance in Ireland. In "The Inquisitor Considers the Daughters of Eve", you reflect about the issue of abort (a highly controversial topic until very recently) and the traditional aversion towards the female body. What would you like to comment in this respect? 
TD: If I write about something which has a political relevance it is always because the poem itself started up in its own preoccupation with the question at hand. I have never set out to write a poem, deliberately, on any topic. What comes out as a poem is the result of, I think, a great deal of thought, pressured thought, beyond, behind or beneath my waking consciousness. I have had the great good fortune to be born a feminist, to have had an instinctive empathy with women, to have found no intellectual resistance in myself to a woman's point of view. I am not surprised when such perspectives emerge in a poem except of course that I am always surprised when a poem starts to speak itself in the silence.

I am by instinct, history and conviction a socialist in politics, a Buddhist anarchist by inclination, a pagan by instinct. These things will find their way out in poems, as will my solitariness and gregariousness, and my passion for the sea.

Pv: So, do you associate your work to some overt ideological position/ political allegiance, such as socialism?

TD: My work as a citizen, yes. My life as a poet, no.

Pv: In your oeuvre, the 'poetics of the quotidian' acquires great significance. Social concerns counteract a clearly perceived private sensibility: trivial events, dreams, small defeats, familiar tragedies, love affairs, in short, all those "small things" which little by little mark your existence, gain a high poetical value. In "A Nocturne for Blackpool”, you make a call to: "In a hard time... keep the skill to make legend of the ordinary". Do you feel that you are succeeding in doing that?

TD: Time will tell.

$\mathrm{Pv}$ : In your work, you refer quite often to Russia, country of great poets, but also of a complex and tragic social experience which has marked the history of the 20th century. Why this fascination with Russia?

TD: Akhmatova, Pasternak, Mandelstam and Tsvetayeva, in their different ways, have taught us a kind of spiritual high demotic; they have given us a language in which the different registers of being human in our time can sound most deeply and truly. They are melancholics, in their different ways, victims, too, and powerless in the face of the greater political forces, as we are. At the same time they are compassionate, importunate, defiant and quiet human voices, I feel them beside me in their different sensibilities as if they were Irish in the way I am, or I were Russian in the way they are. They are all pure lyric poets, Orpheans in that sense, who can register the minute truths of the quotidian in poems about eternal things: I should like to be such a poet, though I know I have nothing like their gifts. It's a matter of instinct, I think, also: my instinct is that I should find their talk congenial, their company as revelatory as their poems. All of which is only to point to a mystery: when we love someone, are we capable of explaining to anyone why this should be so? 
$\mathrm{Pv}$ : With the alienation that culture is experiencing in the beginning of this century, and the interference of the mass media in the construction of a fictitious and easy fame, what future do you think awaits poetry, as a literary genre? Furthermore, what is poetry for you, and in particular, which is the role of the poet?; How is that identity constructed?

TD: Fame, mass-media fame or local fame, is of no consequence to a poet, except that it can steal time. Winning the Nobel Prize has not affected the poems Seamus Heaney makes, because Heaney is a true poet, and had long before fame found him he had made his soul. I know that huge demands are made on his time now, and to that extent he has been adversely affected, since time is all you can give a poet, and time is all you can take away. But he's an intelligent as well as a humane man, and he will find a way to take time back for himself.

A poet who can be seduced by easy and fictitious fame is not a true poet, or if she is, and comes to believe in her fame, will cease to be a true poet. I think we should concern ourselves only with true poets.

True fame, that is being famous for doing well what it is you do, may be unavoidable for certain true poets, but those I have known are highly-conscious that it is a gift with a sharp edge: at its best it increases your audience, it means your poems have a greater chance of being read by larger numbers of living human beings; at its worst it means that your work may be appropriated by large numbers of dead souls — but if your spirit is guarded against these it won't affect the important thing, the next poem. And the next.

Can a true poet be destroyed by fame, organic or manufactured? Sometimes, but rarely.

But these are idle thoughts: I have no expectation of fame, in that much, at least, I am a realist.

Poetry will endure as long as language endures — or perhaps language will endure as long as poetry does? Poetry is a primal and ultimate recourse of the human spirit. I do not think poetry is a literary genre, I think poetry comes before literature, exists symbiotically with literature, will still be with us when and if we cease to write. Poetry is the direct speech of the human heart, and comes from outside history. Poetry, to duck down another path, is meta-history. The role of the poet is to make poems, nothing more, nothing less. The person who is the poet has the same responsibilities and choices or options that any human being has. No fewer, no more.

\section{Pv: Do you think that poetry can change our society, culture? If so, how?}

TD: Poetry is always changing our society and culture, like water working underground, carving through bedrock, nourishing life. Poetry is human speech at its most ecologically sophisticated and responsible. Poetry is language conscious of itself in the world, poetry is where human beings go for refuge and strength when the language of human affairs is no longer the language of the intelligent human heart. Tyrants in their hyper-consciousness fear and hate poetry and poets, as they fear anything that is absolutely free and hate what speaks of the world they do not understand. Poetry is part of the eternal pulse of change, and change, life being life, is what animates culture and society. 
Pv: To what sort of audience are you addressing in your works?

TD: People to whom poems matter, or to whom being alive really matters. The same people, really, even if most do not habitually read poetry.

Pv: Which is your first conscious memory of literary creation in your life? What motivated you to write that first poem you thought it could be published? Why did you start writing? Do you remember, more or less?

TD: I was in the Gaeltacht of Corcha Dhuibhne, a part of Kerry in the extreme south west where only Irish is spoken. A woman looked at me across a bar-room floor, and when her eyes met mine I got an electric shock, a real shock, I spilled my drink with the shock. I walked over to her in a trance, asked her if she was going to a dance taking place that night, 4 miles away, said I would meet her there. I walked there through the dark, making a poem for her in my head. That was the first poem I made, but it would be more accurate to say: that was the first time I experienced a poem making itself inside me.

Pv: Apart from poet, you have also been editor of anthologies, and broadcaster of a wide variety of literary programmes on both radio and television. How do you bring into line writing with all these activities?

TD: With great difficulty. The worst time in my life, in some ways, was the 11 years I spent as Director of Poetry Ireland, the national poetry organisation. I became so good at administration, so preoccupied with developing resources for poets and audiences, as well as occupied with all the things you mention (and more, far more) that I forgot how to be silent inside, how to be there, ready to listen, if a poem came. That's why I resigned from everything. I still want to write prose, edit anthologies, make radio and TV programmes, but now the poems come first: I ask, when something presents itself, can I spare the time from making poems? Of course, I also have to make a living! I am still a practical person, I hope.

Pv: In your work, the European tradition of poetry is constantly present: Tennyson, Rimbaud, Mandelstam and Lorca, among others, are some of the names that come to my mind after reading your poetry. What writers interest you at present?

TD: At present? Right now, you mean? In poetry, Machado for his leanness, Gary Snyder for much the same reason, Neruda again — to refresh my memory. In prose, Doris Lessing and Juan Goytisolo whom I've just discovered. I'm reading a great deal of Frank O’Connor, for work reasons.

Pv: I wouldn't like to finish this interview without asking you which are your coming projects... 
TD: Coming projects... well, I've started writing poems again, after a long silence, but I'm too superstitious to talk about that. I've just finished a non-fiction book about sailing from Antigua to Ireland, a journey I made last summer. I've resumed translating a FrancoLebanese poet, very good, called Venus Khoury Ghata, I've been commissioned to write a libretto for a piece of music to have its premiere in London this summer and I'm writing and will present a TV documentary on the short-story writer, Frank O'Connor. Otherwise I'm just sitting here at my window, looking out at our new dog playing with her new friends. And, I nearly forgot, I'm thinking of a novel. 